http://dx.doi.org/10.18778/1509-877X.2018.01.02

Artykuły

Aleksandra Wrzesińska-Nowacka*

\title{
OPODATKOWANIE DOCHODÓW ZAGRANICZNEJ SPÓŁKI KONTROLOWANEJ W ORZECZNICTWIE SĄDÓW ADMINISTRACYJNYCH
}

Streszczenie. Autorka analizuje orzecznictwo sądów administracyjnych dotyczące zagranicznej spółki kontrolowanej. Orzeczenia zapadły w sprawach ze skarg na indywidualne interpretacje przepisów prawa podatkowego. Zwraca uwagę na uwzględnianie przez sądy przy wykładni regulacji o CFC celu regulacji i dość szerokie interpretowanie pojęć: „udział w kapitale”, „przychody pasywne”. Wyraża pogląd, że wprowadzenie tych rozwiązań również w odniesieniu do osób fizycznych, mimo braku takiego obowiązku wynikającego z prawa unijnego, mogło być reakcją ustawodawcy na działania podatników - osób fizycznych, zmierzające do wykorzystania spółek zagranicznych osiągających przychody pasywne do obniżenia opodatkowania.

Słowa kluczowe: unikanie opodatkowania, zagraniczna spółka kontrolowana, udział w kapitale, przychody pasywne

\section{WPROWADZENIE}

Nasilenie się zjawiska unikania opodatkowania, także poprzez wykorzystanie inwestycji zagranicznych, wymusiło na Organizacji Współpracy Gospodarczej i Rozwoju (OECD), Unii Europejskiej (UE) i ustawodawcach krajowych poszukiwanie środków prawnych mających zapewnić realizację zasady płacenia podatków w państwie, w którym generowane są zyski i wytwarzana jest wartość. Działanie podatników doprowadziło do wypracowania w wielu państwach (w tym również w państwach Unii Europejskiej,

* Sędzia Naczelnego Sądu Administracyjnego, e-mail: awrzesinska@nsa.gov.pl 
m.in. w Niemczech, Finlandii, Portugalii i Estonii, oraz innych, m.in. w Stanach Zjednoczonych, Izraelu, Turcji i Chinach) akceptowanego na arenie międzynarodowej mechanizmu zagranicznej spółki kontrolowanej (Controlled Foreign Company - CFC). Zapobieganie erozji podstawy opodatkowania poprzez CFC odbywa się poprzez poddanie opodatkowaniu w danym państwie, jako dochodu przypisywanego do podmiotu krajowego, dochodu ustalonego w odniesieniu do zysków, jakie osiągnął jego podmiot zależny będący rezydentem podatkowym innego państwa. Podmiot dominujący ma obowiązek uwzględnienia w podstawie opodatkowania dochodów kontrolowanych podmiotów zagranicznych mających siedzibę lub zarząd w kraju o niższym niż obowiązujący w państwie rezydencji podmiotu dominującego poziomie opodatkowania, jeżeli podmiot zależny uzyskuje (w znaczącej części) dochody o charakterze pasywnym ${ }^{1}$. Ze względu na to, że stosowanie tego mechanizmu może prowadzić do podwójnego opodatkowania w sensie ekonomicznym i prawnym, zazwyczaj przepisy dotyczące CFC zawierają także regulacje, które mają zapobiegać temu zjawisku².

\section{STANOWISKo OECD i TSUE}

Regulacje dotyczące CFC co do zasady uznaje się za zgodne z Modelową Konwencją OECD. W komentarzu do jej art. 10 wskazuje się, że dopuszczalne jest zwiększenie na podstawie przepisów krajowych podstawy opodatkowania w kraju siedziby rezydenta - udziałowca CFC o zyski tej ostatniej i że tego rodzaju regulacja nie jest sprzeczna $\mathrm{z}$ umowami o unikaniu podwójnego opodatkowania pod warunkiem, że jest ona stosowana wyłącznie w celu wyeliminowania nadużyć zmierzających do unikania albo odroczenia opodatkowania ${ }^{3}$. OECD rekomendowała jednocześnie stosowanie regulacji dotyczących CFC do dochodów zagranicznych stałych zakładów, jeżeli dochód taki jest wyłączony z opodatkowania w państwie

${ }^{1}$ M. Rudnicki, Ł. Szczygielski, Przeglad regulacji CFC $w$ wybranych państwach Unii Europejskiej w rok po wyroku ETS w sprawie Cadbury Schweppes (C-196/04), „Monitor Podatkowy" 2007, nr 9, s. 11.

${ }^{2}$ B. Kuźniacki, Opodatkowanie zagranicznych spółek kontrolowanych (CFC). Konieczność reformy, Wolters Kluwer 2017, rozdz. 3.3, LEX.

${ }^{3}$ A. Trzópek, Opodatkowanie zagranicznych spółek kontrolowanych, pkt 3.3.3, [w:] Opodatkowanie dochodów transgranicznych, red. M. Jamroży, Wolters Kluwer, Warszawa 2016. 
stosującym mechanizm CFC. Zwracała jednak uwagę na konieczność uwzględnienia przy konstruowaniu przepisów prawnych dotyczących CFC treści postanowień umów o unikaniu podwójnego opodatkowania, zwłaszcza wyłączeń od opodatkowania. Zalecała dokonanie uważnego przeglądu przepisów tych umów podczas projektowania przepisów o CFC w celu upewnienia się, że dochód opodatkowany zgodnie z przepisami o CFC nie podlega metodzie wyłączenia na podstawie tych umów ${ }^{4}$.

Stosowanie tego rodzaju mechanizmu przez państwa - członków Unii Europejskiej budziło pewne wątpliwości co do jego zgodności z zasadami swobody przepływu osób i swobody przedsiębiorczości. Ostatecznie Trybunał Sprawiedliwości Unii Europejskiej (TSUE) (wówczas Europejski Trybunał Sprawiedliwości) w wyroku z 12 września 2006 r. w sprawie C-196/04 Cadbury Schweppes plc i Cadbury Schweppes Overseas Ltd przeciwko Commissioners of Inland Revenue ${ }^{5}$ uznał, że przy spełnieniu określonych przesłanek regulacje krajowe dotyczące CFC nie będą naruszały zasady swobody przedsiębiorczości. Stwierdził, że sama okoliczność, iż spółka będąca rezydentem tworzy drugi zakład taki jak spółka zależna w innym państwie członkowskim w celu obniżenia opodatkowania, nie może uzasadniać ogólnego domniemania oszustwa podatkowego i usprawiedliwiać środka naruszającego wykonywanie swobód podstawowych zagwarantowanych przez traktat. Środek krajowy ograniczający swobodę przedsiębiorczości może natomiast być usprawiedliwiony motywami zwalczania praktyk stanowiących nadużycie, jeżeli dotyczy on właśnie czysto sztucznych struktur, w oderwaniu od przyczyn ekonomicznych, których celem jest uniknięcie stosowania przepisów danego państwa członkowskiego, a w szczególności uniknięcie podatku należnego z tytułu dochodu osiągniętego z działalności na terytorium krajowym. Artykuły 43 i 48 Traktatu ustanawiającego Wspólnotę Europejską ${ }^{6}$ należy, zdaniem Trybunału, interpretować $\mathrm{w}$ ten sposób, że sprzeciwiają się one uwzględnieniu w podstawie opodatkowania spółki będącej rezydentem $\mathrm{z}$ siedzibą $\mathrm{w}$ państwie członkowskim dochodu osiągniętego przez kontrolowaną spółkę zagraniczną w innym państwie członkowskim, jeżeli dochód ten podlega tam niższemu poziomowi opodatkowania niż stosowany w pierwszym państwie, chyba że takie uwzględnienie dotyczy jedynie czysto sztucznych struktur, których celem jest uniknięcie należnego podatku

${ }^{4}$ B. Kuźniacki, Opodatkowanie..., rozdz. 3.3.

${ }^{5}$ https://eur-lex.europa.eu/legal-content/PL/TXT/PDF/?uri=CELEX:62004CJ0196_ SUM\&from $=\mathrm{EN}$

${ }^{6}$ Dz.U. z 2004 r., Nr 90, poz. 864/2. 
krajowego. Należy zatem zaniechać stosowania takiej formy opodatkowania, jeżeli okaże się, na podstawie elementów obiektywnych i możliwych do sprawdzenia przez osoby trzecie, że niezależnie od istnienia motywów natury podatkowej rzeczona spółka kontrolowana rzeczywiście ma siedzibę w przyjmującym państwie członkowskim i faktycznie wykonuje tam działalność gospodarczą. Stanowisko to zostało potwierdzone w wyroku Trybunału Sprawiedliwości z 13 marca 2007 r. w sprawie C-524/04 Test Claimants in the Thin Cap Group Litigation przeciwko Commissioners of Inland Revenue $^{7}$. Z tego właśnie wyroku oraz z wyroku Trybunału z dnia 3 października 2006 r. w sprawie C-452-/04 Fidium Finanz AG przeciwko Bundesanstalt für Finanzdienstleistungsaufsicht ${ }^{8}$ wyprowadzić można ponadto wniosek, że o ile spółki mające siedzibę w państwie członkowskim mogą się powoływać w takim przypadku na naruszenie zasady swobody przedsiębiorczości, o tyle spółki i podmioty mające siedzibę poza terytorium Unii Europejskiej mogą się powoływać wyłącznie na naruszenie zasady swobody przepływu kapitału. Artykuł 56 Traktatu o funkcjonowaniu Unii Europejskiej nie zawiera bowiem żadnego przepisu, który rozciągałby korzyść z tej zasady na podmioty mające siedzibę poza terytorium Unii Europejskiej. Jeżeli przepis krajowy dotyczy jednocześnie swobodnego świadczenia usług i swobodnego przepływu kapitału, Trybunał nakazuje zbadanie, w jakim zakresie przepis ten wpływa na wykonywanie tych swobód podstawowych i czy w okolicznościach postępowania przed sądem krajowym jedna $\mathrm{z}$ nich ustępuje pierwszeństwa drugiej. Badania danego przepisu dokonuje się zasadniczo wyłącznie w świetle jednej z tych dwóch swobód, jeżeli okaże się, że w danych okolicznościach przed sądem krajowym jedna $\mathrm{z}$ nich ustępuje pierwszeństwa drugiej.

Wprowadzenie przepisów o CFC do prawa unijnego rekomendowała Komisja Europejska, przewidując je w projekcie dyrektywy w sprawie wspólnej skonsolidowanej podstawy opodatkowania, oraz Rada Unii Europejskiej w Rezolucji z 8 czerwca 2010 r. w sprawie koordynacji zasad dotyczących kontrolowanych przedsiębiorstw zagranicznych i niedostatecznej kapitalizacji w Unii Europejskiej (2010/C 156/01) ${ }^{9}$. Ostatecznie Rada przyjęła 12 lipca 2016 r. Dyrektywę nr 2016/1164 ustanawiającą przepisy

${ }^{7}$ http://curia.europa.eu/juris/liste.jsf?language $=$ pl\&num $=$ C-524/04

${ }^{8}$ Zb.Orz. s. I-9521; zob. też opinia Rzecznika Generalnego Pedra Ruiza Villalona w sprawie C-47/12, http://curia.europa.eu/juris/document/document.jsf?text=\&docid= 144205\&pageIndex $=0 \&$ doclang $=$ pl\&mode $=$ req \&dir $=\&$ occ $=$ first $\&$ part $=1 \& \mathrm{cid}=7050702$

${ }^{9}$ COM(2011) 121, Decyzja ostateczna z 16 marca 2011 r., 2011/0058 (CNS) (Dz.Urz. UE C 156, s. 1). 
mające na celu przeciwdziałanie praktykom unikania opodatkowania, które mają bezpośredni wpływ na funkcjonowanie rynku wewnętrznego ${ }^{10}$ (dalej: Dyrektywa ATAD). W art. 7 i 8 tej Dyrektywy zawarto regulacje dotyczące zagranicznej spółki kontrolowanej. Przepisy prawa krajowego państw członkowskich zapewniające wykonanie Dyrektywy ATAD powinny być wprowadzone do 31 grudnia $2018 \mathrm{r}$.

\section{ZAGRANICZNA SPÓŁKA KONTROLOWANA W PRAWIE POLSKIM}

Polski ustawodawca zdecydował się na wprowadzenie regulacji o CFC do ustaw o podatkach dochodowych jeszcze przed przyjęciem Dyrektywy ATAD. Ustawą z dnia 29 sierpnia 2014 r. o zmianie ustawy o podatku dochodowym od osób prawnych, ustawy o podatku dochodowym od osób fizycznych oraz niektórych innych ustaw ${ }^{11}$ dodano art. 24a w Ustawie z dnia 15 lutego 1992 r. o podatku dochodowym od osób prawnych ${ }^{12}$ (dalej: u.p.d.o.p.), a w Ustawie z dnia 26 lipca 1991 r. o podatku dochodowym od osób fizycznych ${ }^{13}$ (dalej: u.p.d.o.f.) do art. 10 ust. 1 dodano pkt 8a i dodano art. 30f. Rozwiązania w obu ustawach są prawie identyczne, uwzględniają jedynie istniejące już odrębności, jak choćby konieczność przypisania przychodu osiągniętego przez osobę fizyczną do określonego ustawowo źródła przychodów. Różnice te nie są jednak na tyle istotne, aby co do regulacji wspólnych pozwalać na odmienną ich interpretację. Przepisy te weszły w życie z dniem 1 stycznia 2015 r. Do tej daty w polskim ustawodawstwie nie było rozwiązań skutecznie blokujących możliwość wykorzystania inwestycji bezpośrednich w spółki mające siedzibę w innym państwie niż podmiot inwestujący do obniżenia opodatkowania lub odroczenia powstania obowiązku podatkowego. Jak wynika z orzecznictwa sądów administracyjnych (dotyczącego w przeważającej części kontroli interpretacji podatkowych), podatnicy wykorzystywali wcześniej tego rodzaju rozwiązania w celu unikania opodatkowania. Tworzyli (lub planowali utworzyć) spółki zależne (kapitałowe lub transparentne podatkowo w państwach ich siedziby i traktowane jako zakład w rozumieniu umów o unikaniu podwójnego opodatkowania) osiągające dochody o charakterze pasywnym (z lokat,

\footnotetext{
${ }^{10}$ Dz.Urz. UE L 2016.193.1.

${ }^{11}$ Dz.U. z 2014 r., poz. 1328 ze zm.

12 Tekst jedn. Dz.U. z 2018 r., poz. 1036.

13 Tekst jedn. Dz.U. z 2018 r., poz. 1509.
} 
obrotu akcjami i udziałami w spółkach kapitałowych) w innych państwach, o znacząco niższym opodatkowaniu tego rodzaju dochodów. Przedstawiano więc schematy działania, jakie prowadzić miały do unikania opodatkowania w kraju rezydencji dochodów osiąganych za pośrednictwem spółek z siedzibą za granicą, poprzez tworzenie spółek nieprowadzących rzeczywistej działalności gospodarczej. W większości wypadków, ze względu na treść przepisów krajowych, a także treść bilateralnych umów o unikaniu podwójnego opodatkowania, podatnicy uzyskiwali potwierdzenie, że tego rodzaju dochody nie będą opodatkowane w kraju ich rezydencji lub będą opodatkowane z zastosowaniem odpowiedniej metody unikania podwójnego opodatkowania ${ }^{14}$. Wprowadzenie regulacji dotyczącej zagranicznej spółki kontrolowanej było zatem potrzebne dla utrzymania suwerenności podatkowej i uszczelnienia systemu podatkowego.

Przepisy krajowe dotyczące CFC ulegały zmianom. Pierwsza z nich była konieczna ze względu na zmiany w innych przepisach ustaw o podatkach dochodowych ${ }^{15}$. Druga, istotna, bo w założeniu ustawodawcy mająca na celu implementowanie do prawa polskiego Dyrektywy ATAD ${ }^{16}$, weszła w życie 1 stycznia 2018 r. ${ }^{17}$ Zmian dokonano w obu ustawach o podatku dochodowym, zachowując regulację dotyczącą CFC, chociaż dyrektywa odnosi się wyłącznie do podatników podatku dochodowego od osób prawnych (art. 1 ust. 1 Dyrektywy ATAD) i tylko w tym zakresie obligowała państwa członkowskie do wprowadzenia przepisów o CFC. Nowelizacja dotyczyła zmiany definicji spółki zagranicznej poprzez wprowadzenie zasady, że o uznaniu danego podmiotu za spółkę zagraniczną decyduje posiadanie przez podatnika krajowego udziałów w sposób bezpośredni i pośredni, ale (odmiennie niż w poprzednim stanie prawnym) samodzielnie lub łącznie $\mathrm{z}$ innymi powiązanymi podmiotami. Pojęcie podmiotu powiązanego

${ }^{14}$ Por. wyroki Naczelnego Sądu Administracyjnego: z 3 czerwca 2016 r., sygn. II FSK 1025/14; z 13 lipca 2016 r., sygn. II FSK 1692/14 - wszystkie powołane orzeczenia sądów administracyjnych dostępne w Centralnej Bazie Orzeczeń Sądów Administracyjnych, http://orzeczenia.nsa.gov.pl

${ }^{15}$ Ustawa z dnia 5 września 2016 r. o zmianie ustawy o podatku dochodowym od osób fizycznych i ustawy o podatku dochodowym od osób prawnych (Dz.U. z 2016 r., poz. 1550).

${ }^{16}$ Druk sejmowy nr 1878/VIII kadencja.

${ }^{17}$ Ustawa z dnia 27 października 2017 r. o zmianie ustawy o podatku dochodowym od osób fizycznych, ustawy o podatku dochodowym od osób prawnych oraz ustawy o zryczałtowanym podatku dochodowym od niektórych przychodów osiąganych przez osoby fizyczne (Dz.U. z 2017 r., poz. 2175). 
zostało zdefiniowane także w ustawach, przy czym definicje te nieznacznie się różnią ze względu na charakter podatników ${ }^{18}$. Istotnie zmodyfikowano również przesłanki uznania spółki innej niż spółka mająca siedzibę lub zarząd w raju podatkowym lub państwie, z którym Polski ani Unii Europejskiej nie wiążą umowy międzynarodowe, za zagraniczną spółkę kontrolowaną poprzez znaczące podwyższenie minimalnej wysokości udziału podatnika w zagranicznej spółce, przy czym przy obliczaniu tego progu brany jest pod uwagę udział pośredni i bezpośredni oraz wielkość udziałów posiadanych przez podmioty powiązane. Obniżono natomiast udział przychodów pasywnych w przychodzie spółki zagranicznej dla uznania jej za CFC i rozszerzono katalog tych przychodów (powtórzono katalog z dyrektywy). Zmieniono ponadto zasady ustalania stawki podatkowej stanowiącej o uznaniu przychodów za uzyskane od CFC. Ustawodawca obecnie nakazuje porównać efektywne opodatkowanie w państwie siedziby spółki z hipotetycznym opodatkowaniem, jakiemu podlegałaby w Polsce (zgodnie z zasadą wynikającą z art. 7 ust. 1 pkt b Dyrektywy ATAD). Zwiększono zakres obowiązku prowadzenia rejestru zagranicznych spółek poprzez ujmowanie w nich także tych spółek, które prowadzą rzeczywistą działalność gospodarczą, jednakże działalność ta nie może być uznana za istotną. Ustawodawca nakazał przy tym badanie charakteru działalności poprzez porównanie w szczególności przychodów CFC z rzeczywistej działalności gospodarczej do jej przychodów ogółem (art. 24a ust.18a o.p.d.o.p., art. 30f ust. 20a u.p.d.o.f.), nie określił wszakże, jaki współczynnik potwierdza istotny charakter prowadzonej działalności gospodarczej. Zniesiono próg przychodów, poniżej którego przychody osiągane przez zagraniczną spółkę nie podlegały regułom opodatkowania CFC, choć dyrektywa przewiduje taką możliwość.

Zachowanie regulacji dotyczących zagranicznej spółki kontrolowanej także w odniesieniu do osób fizycznych niewątpliwie pozwala ustawodawcy na uszczelnienie systemu podatkowego również w odniesieniu do tej grupy podatników. Przepisy odnoszą się przy tym - ze względu na określoną wysokość udziałów - wyłącznie do inwestycji bezpośrednich ${ }^{19}$. Inwestycje

${ }^{18} \mathrm{~W}$ u.p.d.o.f. podmiotem powiązanym jest również małżonek podatnika, a także jego krewni do drugiego stopnia; z oczywistych względów osoby te nie zostały wymienione w definicji podmiotu powiązanego w u.p.d.o.p.

${ }^{19}$ Przez inwestycje bezpośrednie w orzecznictwie rozumie się takie, które służą ustanowieniu lub utrzymaniu trwałych i bezpośrednich powiązań między inwestorem a przedsiębiorstwem, któremu ten inwestor udostępnia kapitał w celu prowadzenia działalności 
uznawane za portfelowe ${ }^{20}$ nie są objęte zakresem tego przepisu. Wydaje się jednak, że w przypadku inwestycji osób fizycznych, wobec znacznych obowiązków ewidencyjnych związanych z tą regulacją, zasadne byłoby zachowanie progu kwotowego przychodów zagranicznej spółki kontrolowanej, poniżej którego stosowanie tych przepisów byłoby wyłączone.

Sprawy dotyczące dochodów z zagranicznej spółki kontrolowanej (w wyniku skarg na indywidualne interpretacje prawa podatkowego) były już przedmiotem kontroli sądów administracyjnych. Orzeczenia prawomocne dotyczą stanu prawnego przed ostatnią zmianą, jednakże część $\mathrm{z}$ nich zachowała aktualność.

\section{Pojęcie udZialu W KaPitale}

W wyroku z 30 sierpnia 2016 r., sygn. III SA/Wa 2167/15, Wojewódzki Sąd Administracyjny w Warszawie dokonał wykładni pojęcia „pośredni udział w kapitale”. Przyjął, że w przypadku struktury holdingowej, jaką zamierzał stworzyć skarżący, będący polską spółką kapitałową i polskim rezydentem, spółka nazwana celową spełniająca przesłanki zagranicznej spółki kontrolowanej dla spółki zagranicznej, traktowanej w państwie jej siedziby jak osoba prawna i podlegającej w tym państwie opodatkowaniu od całości swoich dochodów, w której skarżąca będzie posiadać udział w kapitale, prawo głosu w organach kontrolnych lub stanowiących lub prawo do uczestnictwa w zysku (w wysokości wynikającej z art. 24a ust. 3 pkt 3 u.p.d.o.p.), będzie zagraniczną spółką kontrolowaną także dla skarżącej. Skarżąca będzie zatem podlegać opodatkowaniu od dochodów spółki celowej na podstawie art. 24a ust. 1 u.p.d.o.p. i będzie zobowiązana do wypełniania obowiązków dokumentacyjnych, o których mowa w art. 24a ust. 13 u.p.d.o.p.

Z kolei w wyroku Wojewódzkiego Sądu Administracyjnego w Warszawie z 15 września 2016 r., sygn. III SA/Wa 2203/15, na tle tożsamego zdarzenia przyszłego wyrażono pogląd, że pojęcie „udział w kapitale” należy rozumieć szeroko. Chodzi w nim o każdy określony poziom zaangażowania

gospodarczej, zob. wyrok TSUE z 24 listopada 2016 r., SECIL, C-464/14, EU:C:2016:896 i przytoczone tam orzecznictwo.

${ }^{20}$ Tym pojęciem określa się nabywanie papierów wartościowych na rynku kapitałowym wyłącznie w celu lokaty kapitału, bez zamiaru wpływania na zarządzanie i kontrolę przedsiębiorstwa, zob. wyrok TSUE z 21 grudnia 2016 r., AGET Iraklis, C-201/15, EU:2016:972. 
kapitałowego polskiej spółki w zagraniczną spółkę, którego osiągnięcie oznacza, że polska spółka będzie wywierać istotny wpływ na funkcjonowanie spółki zagranicznej. Bez znaczenia jest, czy udział ma charakter pośredni czy bezpośredni. Za takim szerokim rozumieniem pojęcia udziału przemawia również cel wprowadzonej regulacji, jakim jest zwalczanie nadużyć podatkowych.

W wyroku z 29 grudnia 2016 r., w sprawie o sygn. III SA/Wa 2799/15, Wojewódzki Sąd Administracyjny w Warszawie uznał, że użyte w art. $30 \mathrm{f}$ ust. 3 pkt 3 u.p.d.o.f. pojęcie „udział” należy rozumieć szerzej, niż wynika to $\mathrm{z}$ kontekstu, $\mathrm{w}$ jakim zwrot ten jest wykorzystywany w Ustawie z dnia 15 września 2000 r. Kodeks spółek handlowych ${ }^{21}$. Chodzi tu mianowicie o każdy określony poziom zaangażowania kapitałowego polskiego podatnika w zagranicznej spółce, którego osiągnięcie oznacza, że podatnik będzie wywierać istotny wpływ na funkcjonowanie tej spółki. Z tych powodów sąd przyjął, że w przypadku gdy skarżący, będący osobą fizyczną mającą miejsce zamieszkania na terytorium Rzeczypospolitej Polskiej i podlegającą w Polsce nieograniczonemu obowiązkowi podatkowemu w podatku dochodowym od osób fizycznych, stał się uczestnikiem funduszu inwestycyjnego zamkniętego (dalej: FIZ) z siedzibą na terytorium Rzeczypospolitej Polskiej, działającego na podstawie przepisów Ustawy z dnia 27 maja 2004 r. o funduszach inwestycyjnych ${ }^{22}$ (dalej: u.o.f.i.), posiadał certyfikaty inwestycyjne FIZ nieprzerwanie przez okres ponad 30 dni, a FIZ lokował środki pieniężne $\mathrm{w}$ różnorodne przedsięwzięcia inwestycyjne na terytorium Unii Europejskiej, Europejskiego Obszaru Gospodarczego oraz innych państw (m.in. papiery wartościowe i inne instrumenty finansowe emitowane przez podmioty mające siedzibę na terytorium Unii Europejskiej, Europejskiego Obszaru Gospodarczego oraz innych państw, w tym również na terytorium państw - rajów podatkowych) i posiadał nieprzerwanie przez okres ponad 30 dni co najmniej 25\% udziałów w kapitale lub 25\% praw głosu w organach kontrolnych lub stanowiących lub 25\% udziałów związanych z prawem do uczestnictwa w zyskach tych Spółek, a Spółki te będą spełniały $\mathrm{w}$ tym roku podatkowym warunki $\mathrm{z}$ art. $30 \mathrm{f}$ ust. 3 pkt 3 u.p.d.o.f., to będą one dla skarżącego zagranicznymi spółkami kontrolowanymi na podstawie art. 30f ust. 3 u.p.d.o.f. Co do zasady przepis ten odnosi się do uczestnictwa polskich podatników w rozmaitych podmiotach tworzonych

\footnotetext{
${ }^{21}$ Tekst jedn. Dz.U. z 2013 r., poz. 1030 ze zm.

22 Tekst jedn. Dz.U. z 2014 r., poz. 157.
} 
i funkcjonujących w innych systemach prawnych; sformułowanie „25\% udziałów związanych z prawem do uczestnictwa w zyskach” użyte w ustawie należy zatem interpretować szeroko i odnosić do wszelkich form zaangażowania kapitałowego polskiego rezydenta w zagranicznej spółce.

Sąd, uzasadniając swoje stanowisko, przywołał art. 140 ust. 1 u.o.f.i., zgodnie z którym w funduszu inwestycyjnym zamkniętym działa rada inwestorów, jako organ kontrolny, lub zgromadzenie inwestorów. Zgromadzenie inwestorów to najwyższy organ stanowiący funduszu (art. 144 u.o.f.i.). Może ono w szczególności podjąć uchwałę o rozwiązaniu funduszu, o powierzeniu zarządzania funduszem, zmianie statutu, emisji obligacji, przekształceniu certyfikatów imiennych na certyfikaty na okaziciela; decyduje o znaczniejszych inwestycjach funduszu, zatwierdza sprawozdania finansowe. Zgodnie $\mathrm{z}$ art. 140 u.o.f.i. pełni też funkcje kontrolne w sytuacji, gdy nie powołano rady inwestorów. W przypadku posiadania większości certyfikatów w funduszu (FIZ) inwestor (uczestnik) ma zatem większość głosów w zgromadzeniu inwestorów, a więc ma decydujący wpływ na jego funkcjonowanie. Oznacza to tym samym, że w takim przypadku z posiadaniem certyfikatów wiążą się nie tylko wierzytelności, ale i udział partycypacyjny $\mathrm{w}$ funduszu. Z kolei posiadanie przez ten fundusz większościowego udziału w kapitale zakładowym (lub w udziale w zyskach lub w prawach głosu w organach kontrolnych lub stanowiących) spółki zagranicznej przekłada się na to, że inwestor (uczestnik) posiadający większość certyfikatów w FIZ będzie posiadał pośrednio w spółce zagranicznej co najmniej 25\% udziałów w kapitale (lub udziałach związanych z prawem do uczestniczenia w zyskach lub w prawach głosu w organach kontrolnych lub stanowiących). Spółka zagraniczna będzie wówczas spełniać kryteria określone w art. 30f ust. 3 pkt 3 lit. a u.p.d.o.f. Rada inwestorów z kolei kontroluje realizację celu inwestycyjnego funduszu inwestycyjnego zamkniętego i polityki inwestycyjnej oraz przestrzeganie ograniczeń inwestycyjnych. Jeżeli inwestor (uczestnik) obejmie ponad 5\% ogólnej liczby certyfikatów, może zostać członkiem rady inwestorów. W sytuacji gdy dokona blokady certyfikatów inwestycyjnych, każdy certyfikat będzie mu dawał prawo do jednego głosu w radzie inwestorów. W tym przypadku prawo głosu nie jest związane z posiadaniem udziału w kapitale, lecz z samym posiadaniem certyfikatu. W sytuacji dokonania blokady 25\% ogólnej liczby certyfikatów będzie posiadał w radzie inwestorów $25 \%$ praw głosu. Warunek określony w art. $30 \mathrm{f}$ ust. 3 pkt 3 lit. a u.p.d.o.f. zostanie zatem spełniony, skoro fundusz będzie miał 25\% praw głosu w organach kontrolnych lub stanowiących spółki 
zagranicznej (lub 25\% udziałów w kapitale lub 25\% udziałów w zyskach). Wówczas inwestor (uczestnik) będzie posiadał pośrednio 25\% praw głosu w tej spółce (lub 25\% udziałów w kapitale lub 25\% udziałów w zyskach). W takim przypadku spółka będzie zagraniczną spółką kontrolowaną. Pogląd ten został wyrażony także przez Wojewódzki Sąd Administracyjny w Bydgoszczy w wyroku z 14 października 2015 r., sygn. I SA/Bd 622/15.

\section{PRZYCHOdY PASYWNE}

Sądy administracyjne zajmowały się również pojęciem przychodów pasywnych. Przyjęły, że w pojęciu „odsetek i pożytków od wszelkiego rodzaju pożyczek” mieszczą się też dochody z odsetek od środków gromadzonych na lokatach i rachunkach bankowych. Za szerokim rozumieniem odsetek opowiedziały się m.in.: Wojewódzki Sąd Administracyjny w Kielcach w wyroku z 16 listopada 2015 r., sygn. I SA/Ke 563/15 ${ }^{23}$, Wojewódzki Sąd Administracyjny w Warszawie w wyroku z 29 grudnia 2016 r., sygn. III SA/Wa 2624/15 oraz Naczelny Sąd Administracyjny w wyrokach z 6 marca 2018 r. w sprawach o sygn. II FSK 472/16 i II FSK 668/16. Naczelny Sąd Administracyjny podzielił stanowisko sądu pierwszej instancji, że art. 24a ust. 3 pkt 3 lit. b u.p.d.o.p. nie ogranicza się wyłącznie do odsetek i pożytków od pożyczek de iure civili. Poprzez posłużenie się w przepisie zwrotem „wszelkiego rodzaju” (w kontekście owych pożyczek) poszerzono zakres przypadków, w których przepis ma zastosowanie do wszelkich stosunków prawnych zbliżonych treścią do pożyczki, tj. takich, w ramach których dochodzi do udostępnienia innej osobie kapitału za wynagrodzeniem w postaci odsetek. Analizując umowę rachunku bankowego (strona pytała o odsetki od środków na rachunkach bankowych), sąd zwrócił uwagę, że w piśmiennictwie i orzecznictwie wskazuje się, iż umowa ta łączy w sobie elementy umowy depozytu nieprawidłowego (art. 845 Kodeksu cywilnego ${ }^{24}$, dalej: k.c.) z elementami umowy zlecenia (art. 734 k.c.), przy czym - poprzez art. 845 k.c. - do umowy tej będą miały zastosowanie także przepisy o pożyczce (art. 720 k.c.). Stąd też posiadacz rachunku bankowego z chwilą wpłaty pieniędzy do banku traci ich własność na rzecz banku, a nabywa roszczenie o zwrot takiej samej ich ilości. Konsekwencją takiej

${ }^{23}$ Skargę kasacyjną od tego wyroku Naczelny Sąd Administracyjny oddalił wyrokiem z 6 marca 2018 r., sygn. II FSK 472/16, tylko z nieco inną argumentacją.

${ }^{24}$ Tekst jedn. Dz.U. z 2019 r., poz. 1145. 
konstrukcji jest - w każdym przypadku - nabycie własności środków pieniężnych przez bank oraz nabycie przez posiadacza rachunku roszczenia o zwrot wpłaconych środków. Nie może zatem budzić wątpliwości, że treść uprawnień i obowiązków stron umowy rachunku bankowego obejmuje elementy typowe (charakterystyczne) dla pożyczki w ustalonym powyżej rozumieniu. Pojęcie pożyczki wszelkiego rodzaju nie zostało wprawdzie wprost zdefiniowane w ustawie, ale należy uznać, że w tym przypadku prawo podatkowe odwołało się do pojęcia mającego ustaloną treść zarówno w prawie cywilnym, jak i w języku potocznym, a jednocześnie - na gruncie spornego przepisu - nadało mu szczególne znaczenie poprzez rozszerzenie jego zakresu w porównaniu ze znaczeniem cywilistycznym oraz tym z języka potocznego. W ramach autonomii prawa podatkowego ustawodawca ma bowiem możliwość tworzenia rozwiązań swoistych dla tej gałęzi prawa, jeżeli służyć to ma interesowi Skarbu Państwa i jednocześnie nie zakłóca funkcjonowania instytucji cywilnoprawnych.

W wyrokach z 6 marca 2018 r., sygn. II FSK 551/16 i II FSK 640/16, Naczelny Sąd Administracyjny uznał za przychody, o których mowa w art. 24a ust. 3 pkt 3 lit. b u.p.d.o.p., przychody ze zbycia lokat funduszy inwestycyjnych zamkniętych i wypłaty dochodów przez fundusz inwestycyjny zamknięty. Wyroki zapadły w analogicznych stanach faktycznych (we wniosku o interpretację przedstawiono zdarzenia przyszłe). Skarżący, będący polskimi rezydentami podatkowymi, posiadają udziały w kapitale zakładowym spółki prawa cypryjskiego (odpowiednika polskiej spółki z ograniczoną odpowiedzialnością), mającej siedzibę i zarząd na terytorium Republiki Cypru (dalej: spółka cypryjska). Skarżący spełniali przesłanki z art. 24a ust. 3 pkt 3 lit. a u.p.d.o.p. Podstawowym przedmiotem działalności gospodarczej spółki cypryjskiej jest działalność inwestycyjna. Spółka ta posiada certyfikaty inwestycyjne stanowiące tytuły uczestnictwa $\mathrm{w}$ funduszach inwestycyjnych zamkniętych (dalej: Fundusze) z siedzibą w Polsce. W przyszłości może osiągnąć dochody ze zbycia lokat Funduszy, tj. zgodnie z art. 198 u.o.f.i. Możliwe jest również, że na podstawie statutu Funduszy, tj. na podstawie art. 18 ust. 2 pkt 13 u.o.f.i., na rzecz spółki cypryjskiej zostaną wypłacone dochody tych Funduszy (dalej: dochody Funduszy). Wypłaty przychodów ze zbycia lokat Funduszy, a także z dochodów Funduszy nie będą wymagać wykupywania przez spółkę cypryjską certyfikatów inwestycyjnych w Funduszach. Być może na moment dokonania wypłat przychody (dochody) z tytułu tych przychodów będą podlegać zwolnieniu z opodatkowania podatkiem dochodowym na 
Cyprze i stanowić ponad 50\% przychodów spółki cypryjskiej. Skarżący pytali, czy tego rodzaju przychody mogą być traktowane jako przychody powodujące nadanie spółce cypryjskiej statusu CFC (przy spełnieniu pozostałych warunków wskazanych w art. 24a ust. 3 pkt 3 u.p.d.o.p.). Naczelny Sąd Administracyjny podzielił stanowisko sądu pierwszej instancji i organu interpretującego i uznał, że tego rodzaju dochody stanowią dochody $z$ realizacji praw $z$ instrumentów finansowych. Pojęcie „przychód $\mathrm{z}$ realizacji praw z instrumentów finansowych" nie zostało zdefiniowane ani w art. 24a ust. 2 u.p.d.o.p., w którym zamieszczono definicje określeń ustawowych na potrzeby stosowania art. 24a, ani w innych przepisach u.p.d.o.p., czy też w innych przepisach prawa podatkowego, jednak w art. 24a ust. 2 pkt 2 u.p.d.o.p. przyjęto, że określenie „instrumenty finansowe" oznacza instrumenty finansowe wymienione w art. 2 Ustawy z dnia 29 lipca 2005 r. o obrocie instrumentami finansowymi ${ }^{25}$ (dalej: u.o.i.fin.). Zgodnie zaś $\mathrm{z}$ art. 2 ust. 1 u.o.i.fin. instrumentami finansowymi w rozumieniu ustawy są m.in. papiery wartościowe. Zgodnie natomiast $\mathrm{z}$ art. 3 pkt 1 lit. a u.o.i.fin., ilekroć w ustawie jest mowa o papierach wartościowych, rozumie się przez to akcje, prawa poboru w rozumieniu przepisów Ustawy z dnia 15 września 2000 r. Kodeks spółek handlowych ${ }^{26}$, prawa do akcji, warranty subskrypcyjne, kwity depozytowe, obligacje, listy zastawne, certyfikaty inwestycyjne i inne zbywalne papiery wartościowe, w tym inkorporujące prawa majątkowe odpowiadające prawom wynikającym $\mathrm{z}$ akcji lub z zaciągnięcia długu, wyemitowane na podstawie właściwych przepisów prawa polskiego lub obcego. Tym samym, na podstawie art. 3 pkt 1 lit. a u.o.i.fin., certyfikaty inwestycyjne są instrumentami finansowymi stanowiącymi papiery wartościowe. Statut funduszu może przewidywać i określać zasady wypłacania uczestnikom funduszu inwestycyjnego zamkniętego dochodów funduszu (art. 18 ust. 2 pkt 13 u.o.f.i.), także bez wykupywania certyfikatów, jeżeli przewiduje to statut funduszu. Również zgodnie $z$ art. 21 u.o.f.i. dochodami funduszu inwestycyjnego są przychody $z$ lokat netto funduszu inwestycyjnego lub zrealizowany zysk (strata) ze zbycia lokat, a - na podstawie art. 198 ust. 1 u.o.f.i. - statut funduszu inwestycyjnego aktywów niepublicznych może przewidywać wypłacanie na rzecz uczestników funduszu przychodów ze zbycia lokat funduszu, pomniejszonych o koszty działania funduszu związane bezpośrednio ze

25 Tekst jedn. Dz.U. z 2017 r., poz. 1768 ze zm.

26 Tekst jedn. Dz.U. z 2013 r., poz. 1030. 
zbytymi lokatami oraz o część kosztów działania funduszu przypadającą na takie lokaty proporcjonalnie do ich wartości w stosunku do wartości portfela inwestycyjnego funduszu. Certyfikaty inwestycyjne są tytułami uczestnictwa w funduszach inwestycyjnych zamkniętych. Są też papierami wartościowymi, jednakże zarówno ich cechy, jak i zakres związanych z nimi uprawnień może być różny w zależności od postanowień statutu danego funduszu, który je wyemitował. Certyfikaty inwestycyjne są niepodzielne, co prowadzi do nierozdrabniania praw wyrażonych w certyfikacie inwestycyjnym. Prawa związane z nimi to: prawo do udziału w wartości aktywów netto pozostałych do podziału po przeprowadzeniu likwidacji funduszu, prawo do części dochodów funduszu, w przypadku gdy statut przewiduje wypłatę tych dochodów, prawo do przychodów funduszu, w przypadku gdy statut przewiduje ich wypłacanie, prawo do udziału i głosowania na radzie inwestorów lub zgromadzeniu inwestorów, prawo pierwszeństwa do objęcia nowych certyfikatów inwestycyjnych kolejnej emisji. Statut może także przyznawać uczestnikom dodatkowe możliwości i uprawnienia, jak choćby związane z umową gwarancji odkupienia certyfikatów od uczestników przez podmiot wskazany przez fundusz w czasie i po cenie określonej w statucie. Po zakończeniu okresu rozliczeniowego, którego dotyczą wydane certyfikaty, nabywca certyfikatów jest uprawniony do zwrócenia się do funduszu o realizację wynikających $\mathrm{z}$ nich praw. Warunkiem powstania roszczeń o realizację praw wynikających z certyfikatów jest osiągnięcie przez fundusz w danym okresie rozliczeniowym określonego liczbowo poziomu przychodów i dochodów. Podstawowym uprawnieniem związanym z posiadaniem certyfikatów inwestycyjnych jest zatem prawo do udziału $\mathrm{w}$ aktywach netto lub dochodzie funduszu proporcjonalnie do wartości wkładów poszczególnych uczestników. Tym samym dochody te stanowią przychody pasywne spółki zagranicznej.

\section{ZWOLNIENIE OD OPODATKOWANIA}

W kolejnej sprawie o sygn. I SA/Gl 1350/16 Wojewódzki Sąd Administracyjny w Gliwicach wyrokiem z 14 marca 2017 r. oddalił skargę na indywidualną interpretację przepisów prawa podatkowego. Przedmiotem sporu w tej sprawie była wykładnia użytego w art. 24a ust. 3 pkt 3 lit. c u.p.d.o.p. pojęcia „Zwolnienie od opodatkowania”. W tym przypadku dochody spółki zagranicznej, o którą pytał skarżący, opodatkowane są stawką od 28,22\% do $29,22 \%$. Jednak na zasadzie wyjątku, po spełnieniu określonych warunków, 
przychody te mogą podlegać zwolnieniu od podatku dochodowego. Sąd przyjął, że w świetle art. 24a ust. 3 pkt 3 Ustawy z dnia 15 lutego 1992 r. o podatku dochodowym od osób prawnych ${ }^{27}$ zagraniczna spółka zyskuje przymiot zagranicznej spółki kontrolowanej, jeżeli co najmniej jeden z wymienionych $\mathrm{w}$ pkt b rodzajów przychodów w państwie siedziby (zarządu) zagranicznej spółki podlega zwolnieniu bądź wyłączeniu z opodatkowania podatkiem dochodowym $w$ tym państwie, bez względu na to, czy zwolnienie to jest, czy też nie jest obwarowane spełnieniem określonych warunków w państwie siedziby, pod warunkiem spełnienia pozostałych kryteriów wynikających z tego przepisu. W aprobującej glosie do tego wyroku ${ }^{28} \mathrm{D}$. Mączyński zwrócił uwagę, że art. 24a ust. 3 pkt 3 lit. c u.p.d.o.p. nie wprowadza rozróżnienia rodzajów zwolnień. Ustawodawca wprowadza tylko jeden wyjątek od zasady, że zwolnienie podatkowe nie powoduje uznania spółki za CFC. Przyjęcie za trafne stanowiska podatnika, że ze względu na konieczność spełnienia dodatkowych warunków dla zwolnienia warunek z powołanego wyżej przepisu nie jest spełniony, wprowadziłoby wyjątek kolejny. Takiego zaś ustawodawca nie wprowadził.

\section{Prowadzenie ewidencji PRZEZ CFC}

W zakresie obowiązku prowadzenia ewidencji zagranicznych spółek kontrolowanych wypowiedział się z kolei Wojewódzki Sąd Administracyjny w Warszawie w wyroku z 14 października 2016 r., sygn. III SA/Wa $2547 / 15$. Strona będącą zamkniętym funduszem inwestycyjnym, uzyskującym dochody z działalności zagranicznych spółek kontrolowanych, chciała uzyskać stanowisko co do obowiązku prowadzenia stosownej dokumentacji w sytuacji, gdy jej dochody podlegają zwolnieniu. Sąd uznał, że obowiązek prowadzenia rejestru spółek oraz ewidencji zdarzeń gospodarczych, o którym mowa w art. 24a ust. 13 u.p.d.o.p., ciąży również na funduszach inwestycyjnych. W ocenie sądu sam fundusz przyznał w istocie, że obowiązujące obecnie przepisy ustawy traktują $\mathrm{w}$ tym zakresie zwolnione $\mathrm{z}$ opodatkowania fundusze inwestycyjne dokładnie tak samo jak innych podatników, którzy posiadają odpowiednie udziały w zagranicznych spółkach kontrolowanych.

27 Tekst jedn. Dz.U. z 2016 r., poz. 1888 ze zm.

${ }^{28}$ D. Mączyński, Glosa do wyroku WSA w Gliwicach z 14.03.2017 r., I SA/Gl 1350/16, OSP 2018, nr 2, s. 144. 
W dotychczasowym orzecznictwie nie zajęto stanowiska co do tego, czy fundacja prywatna może być uznana za spółkę zagraniczną. W wyroku z 2 października 2017 r., w sprawie o sygn. III SA/Wa 2884/16, Wojewódzki Sąd Administracyjny w Warszawie przyjął jedynie, że art. 30f ust. 2 pkt 1 u.p.d.o.f. określa kilka warunków, których spełnienie jest wymagane dla uznania spółki za spółkę zagraniczną. Nie wystarczy zatem zbadanie, czy podmiot jest wymieniony w katalogu podmiotów działających w określonej w nim formie prawnej, ale także trzeba stwierdzić, czy spełnia on kolejny warunek wymieniony $\mathrm{w}$ tym przepisie in fine i odnoszący się do posiadania przez podatnika udziału w kapitale, prawa głosu w organach kontrolnych lub stanowiących lub prawo do uczestnictwa w zysku. Warunki wymienione w powołanym przepisie muszą bowiem być spełnione łącznie. W piśmiennictwie ${ }^{29}$ wyrażono pogląd, że właśnie ze względu na niespełnienie warunków dotyczących udziału w kapitale, prawa do zysku i wpływu na działania fundacji fundacja prywatna nie może być uznana za CFC w odniesieniu do jej beneficjentów. Podkreślenie przez sąd konieczności spełnienia wszystkich warunków wymienionych w art. 30 f ust. 2 pkt 1 u.p.d.o.f. daje podstawę do stwierdzenia, że sąd problem ten dostrzegł, jednakże wobec braku wypowiedzi w tym zakresie organu interpretującego nie mógł się stanowczo odnieść do tej kwestii.

\section{Podsumowanie}

Przywołane prawomocne orzeczenia sądów administracyjnych świadczą o tym, że sądy przy dokonywaniu wykładni przepisów o zagranicznej spółce kontrolowanej kierują się celem wprowadzenia tej regulacji i przesłanki stanowiące o uznaniu spółki zagranicznej za zagraniczną spółkę kontrolowaną interpretują dość szeroko. Stosunkowo niewielka jeszcze liczba orzeczeń, wydanych ponadto w sprawach dotyczących interpretacji, może świadczyć o tym, że podatnicy próbują się dopiero zorientować, czy planowane przez nich przedsięwzięcia (inwestycje zagraniczne) pozwolą na obniżenie zobowiązań podatkowych. Zmiana przepisów w związku z przyjęciem Dyrektywy ATAD spowodowała, że część poglądów wyrażonych w powołanych wyrokach staje się w obecnym stanie prawnym nieaktualna (m.in. dotyczących obowiązku prowadzenia rejestru czy sposobów obliczania przychodów

${ }^{29}$ A. Mariański, A. Żądło, Opodatkowanie fundacji prywatnych, „Przegląd Podatkowy" 2018, nr 8, s. 25. 
zagranicznej spółki kontrolowanej). Do tej pory nie poruszano w orzecznictwie kwestii zgodności przepisów krajowych z pierwotnym prawem unijnym. Przyjęcie Dyrektywy ATAD może wymusić konieczność oceny prawidłowości implementowania tej dyrektywy do prawa krajowego. Nie można ponadto wykluczyć, że pojawią się również spory dotyczące tej części regulacji, która ma na celu uniknięcie podwójnego opodatkowania ${ }^{30}$, lub na tle stosowania przepisów krajowych i umów o unikaniu podwójnego opodatkowania. Spory mogą także powstać na tle określenia, czy spółka zagraniczna prowadzi istotną rzeczywistą działalność gospodarczą. Wydaje się zatem, że problematyka CFC może być jeszcze niejednokrotnie przedmiotem rozstrzygnięć sądów administracyjnych.

\section{BIBLIOGRAFIA}

Kuźniacki B., Mechanizm unikania wielokrotnego opodatkowania dochodu CFC, „Monitor Podatkowy" 2016, nr 9.

Kuźniacki B., Opodatkowanie zagranicznych spółek kontrolowanych (CFC). Konieczność reformy, Wolters Kluwer 2017.

Mariański A., Żądło A., Opodatkowanie fundacji prywatnych, „Przegląd Podatkowy” 2018, nr 8.

Mączyński D., Glosa do wyroku WSA w Gliwicach z 14.03.2017 r., I SA/Gl 1350/16, OSP 2018, nr 2.

Rudnicki M., Szczygielski Ł., Przeglad regulacji CFC $w$ wybranych państwach Unii Europejskiej w rok po wyroku ETS w sprawie Cadbury Schweppes (C-196/04), „Monitor Podatkowy" 2007, nr 9.

Trzópek A., Opodatkowanie zagranicznych spótek kontrolowanych, pkt 3.3.3, [w:] Opodatkowanie dochodów transgranicznych, red. M. Jamroży, Wolters Kluwer, Warszawa 2016.

\section{TAXATION OF INCOME OF A FOREIGN CONTROLLED COMPANY IN THE CASE LAW OF ADMINISTRATIVE COURTS}

Summary. The author analyzes the jurisprudence of administrative courts regarding a foreign controlled company. These judgments were made in cases related to complaints about individual interpretations of tax law provisions. He draws attention to the fact that the courts take into consideration the regulation's purpose in the interpretation of $\mathrm{CFC}$ regulations and the quite broad interpretation of the terms "share in capital", "passive income". Expresses the view that the introduction of these solutions also in relation to natural persons, despite the absence of such an obligation under EU law, could be a reaction of the legislator to the actions of taxpayers - natural persons, aiming at using foreign companies achieving passive income to reduce taxation.

Keywords: tax avoidance, foreign controlled company, share in capital, passive income

${ }^{30} \mathrm{Na}$ niespełnienie celu tych przepisów wskazywał B. Kuźniacki, Mechanizm unikania wielokrotnego opodatkowania dochodu CFC, „Monitor Podatkowy” 2016, nr 9, s. 21-31. 